\title{
Lifestyle behaviours and health measures of women at increased risk of breast cancer taking chemoprevention.
}

DOI:

10.1097/CEJ.0000000000000493

\section{Document Version}

Accepted author manuscript

Link to publication record in Manchester Research Explorer

\section{Citation for published version (APA):}

Pegington, M., Evans, D., Howell, T., Gorman, L., Wiseman, J., Cuzick, J. M., \& Harvie, M. (2018). Lifestyle behaviours and health measures of women at increased risk of breast cancer taking chemoprevention. European Journal of Cancer Prevention. https://doi.org/10.1097/CEJ.0000000000000493

\section{Published in:}

European Journal of Cancer Prevention

\section{Citing this paper}

Please note that where the full-text provided on Manchester Research Explorer is the Author Accepted Manuscript or Proof version this may differ from the final Published version. If citing, it is advised that you check and use the publisher's definitive version.

\section{General rights}

Copyright and moral rights for the publications made accessible in the Research Explorer are retained by the authors and/or other copyright owners and it is a condition of accessing publications that users recognise and abide by the legal requirements associated with these rights.

\section{Takedown policy}

If you believe that this document breaches copyright please refer to the University of Manchester's Takedown Procedures [http://man.ac.uk/04Y6Bo] or contact uml.scholarlycommunications@manchester.ac.uk providing relevant details, so we can investigate your claim.

\section{OPEN ACCESS}




\section{European Journal of Cancer Prevention}

\section{Lifestyle behaviours and health measures of women at increased risk of breast cancer taking chemoprevention \\ --Manuscript Draft--}

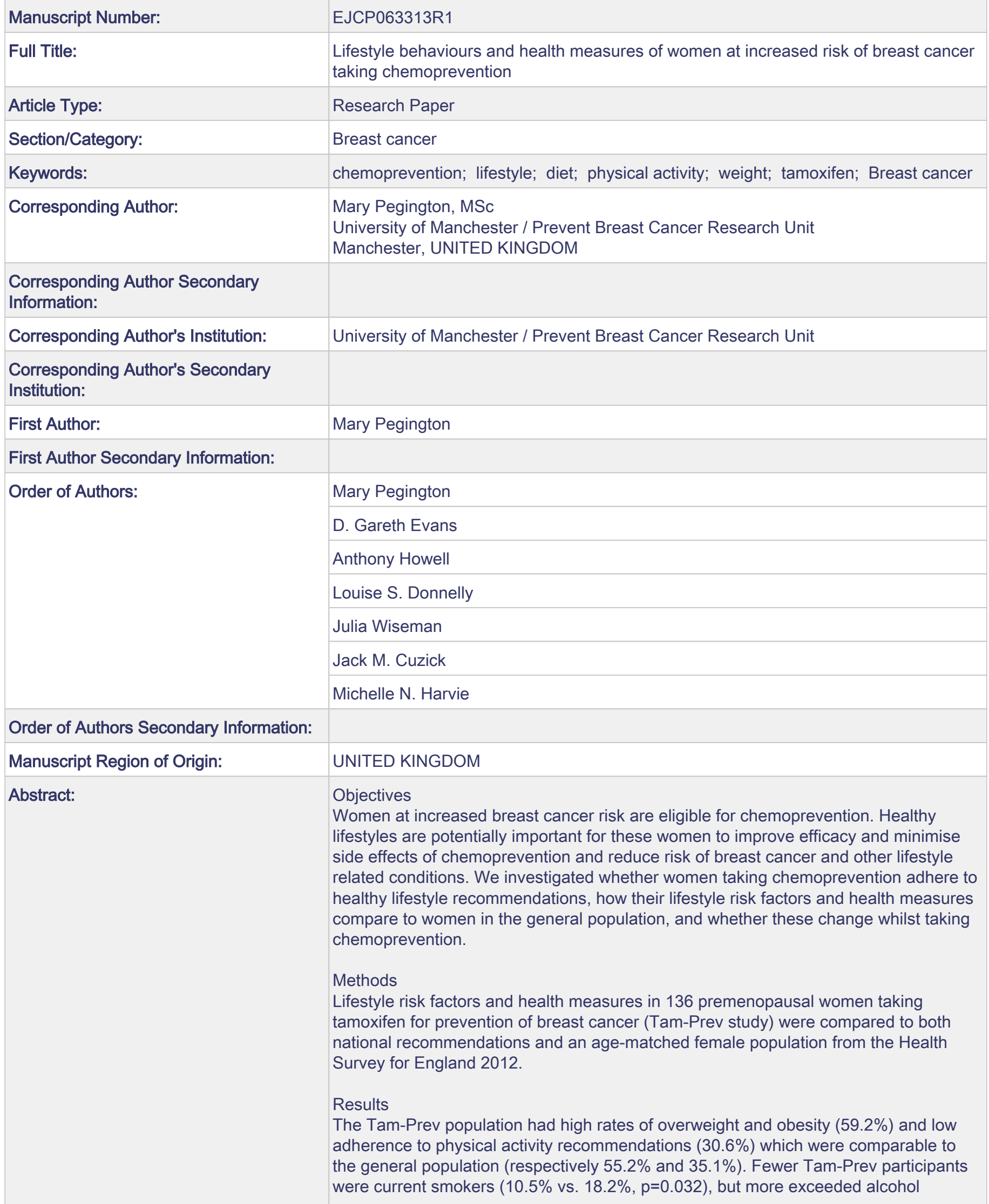


recommendations $(45.0 \%$ vs. $18.7 \%, \mathrm{p}<0.001)$. Tam-Prev participants had suboptimal diets; proportions not meeting fibre, saturated fat and non-milk extrinsic sugar recommendations were $87.8 \%, 64.9 \%$ and $21.4 \%$ respectively. Many Tam-Prev participants had markers of cardiovascular disease risk and the metabolic syndrome. Health behaviours did not change during the first year on tamoxifen.

Conclusions

Women taking chemoprevention had a high prevalence of unhealthy lifestyle behaviours and health measures, similar to an age-matched English cohort. Improving these measures in women at increased breast cancer risk could significantly decrease rates of breast cancer and other non-communicable diseases. 


\section{Manchester University}

NHS Foundation Trust

\section{FAMILY HISTORY CLINIC \\ BREAST CANCER PREVENTION}

Professor Anthony Howell

Professor Gareth Evans
Prevention Breast Cancer Research Unit

The Nightingale Centre

Wythenshawe Hospital

Southmoor Road

Wythenshawe

Manchester

M23 9LT

Tel: +44 (0)161 2914854

mary.pegington@manchester.ac.uk

\section{Professor Jaak Janssens \\ Editor-in-Chief \\ European Journal of Cancer Prevention}

1st August 2018

Dear Professor Janssens,

Please find enclosed our revised submission to the European Journal of Cancer Prevention:

Lifestyle behaviours and health measures of women at increased risk of breast cancer taking chemoprevention

Mary Pegington, D. Gareth Evans, Anthony Howell, Louise S. Donnelly, Julia Wiseman, Jack M. Cuzick and Michelle N. Harvie

We are very grateful to your two reviewers for their helpful comments. I enclose a revised manuscript and below is a point-by-point response.

Reviewer \#1:

1. We have reduced the length of the discussion as recommended.

Reviewer \#2:

1. The comparator group was chosen as the aim of the paper was to investigate whether women at increased risk of breast cancer eligible for chemoprevention are already leading a healthier lifestyle compared to women in the general population. Our statistician advised that the comparing two groups of different sizes was acceptable.

2. The variables that were measured differently in the two cohorts were waist, alcohol and physical activity.

- We have removed reference to waist. Because we also have weight and $\mathrm{BMI}$, we agree that the addition of waist by a different measurement was not adding to the aim of the paper.

- Alcohol and physical activity remain in the paper as they are key determinants of a healthy lifestyle and the manuscript clearly exercises caution over these comparisons.

3. We have reduced the length of the discussion as recommended.

4. We have not included a discussion on the relevance of tamoxifen adherence and changes after treatment which we acknowledge is a very interesting area. We include three participants who were known to have stopped taking tamoxifen before one year but we do not have data on tamoxifen adherence for the other 106 women who completed the Tam-Prev study. The suggested Maurice et al (2006) paper from our research group looked at predictors of compliance and found that not smoking 
was associated with IBIS I study completion. Our manuscript describes no difference in smoking status between completers and those that dropped out of Tam-Prev. We have not gone into further detail with this as it would have added to the length of the discussion and was not the main focus of study. Likewise for the Land et al (2011) paper which showed mixed results for lifestyle and compliance in the NSABP BCPT, the effect of lifestyle on drug compliance was not the main focus of our study and could not be as we lack data on compliance in Tam-Prev.

5. Many thanks for highlighting the discrepancy in whether lifestyle advice was given. We have clarified this by adding that no 'individualised' advice was given (Procedures, line 2; Discussion, paragraph 7).

6. We have not stated that CVD risk is increased by tamoxifen and we agree with the reviewer that evidence suggests that tamoxifen does not increase risk. We have stated that tamoxifen does not lower CVD rates, despite it reducing total and LDL cholesterol levels. We make this point to highlight that many women taking tamoxifen need to act on their raised CVD risk. We have added to this paragraph to clarify our argument (Discussion, paragraph 8).

Please contact me if you require any further clarification or information.

We look forward to hearing from you.

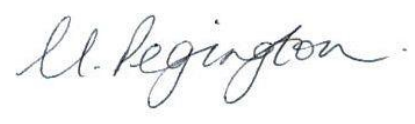

Mrs Mary Pegington

On behalf of Louise S. Donnelly, Julia Wiseman, Jack M. Cuzick, D. Gareth Evans, Anthony Howell and Michelle N. Harvie 
TITLE PAGE

\section{Lifestyle behaviours and health measures of women at increased risk of breast cancer taking chemoprevention}

Running head: Lifestyle of women at increased breast cancer risk

\section{Authors and affiliations:}

Mary Pegington ${ }^{1,2}$, D. Gareth Evans ${ }^{1,2,3,4}$, Anthony Howell ${ }^{1,2,4,5}$, Louise S. Donnelly ${ }^{2}$, Julia Wiseman ${ }^{2}$, Jack M. Cuzick ${ }^{6}$ and Michelle N. Harvie ${ }^{2,4}$

${ }^{1}$ Division of Cancer Sciences, Faculty of Biology, Medicine and Health, University of Manchester, Manchester, M13 9PL, UK

2 Prevent Breast Cancer Research Unit, The Nightingale Centre, Wythenshawe Hospital, Manchester University NHS Foundation Trust, Manchester, M23 9LT, UK

${ }^{3}$ Genomic Medicine, Division of Evolution and Genomic Sciences, The University of Manchester, St Mary's Hospital, Manchester University NHS Foundation Trust, Oxford Road, Manchester, M13 9WL, UK

${ }^{4}$ Manchester Breast Centre, Manchester Cancer Research Centre, University of Manchester, 555 Wilmslow Road, Manchester, M20 4GJ, UK

${ }^{5}$ Department of Medical Oncology, The Christie NHS Foundation Trust, Wilmslow Rd, Manchester M20 4BX, UK

${ }^{6}$ Wolfson Institute of Preventative Medicine, Barts and The London School of Medicine and Dentistry, Charterhouse Square, London, EC1M 6BQ, UK 


\section{Corresponding author:}

Mary Pegington, Research Dietitian, Prevent Breast Cancer Research Unit, The Nightingale Centre, Wythenshawe Hospital, Manchester University NHS Foundation Trust, Manchester, M23 9LT, UK.

Telephone: 01612914854

Email: mary.pegington@manchester.ac.uk

\section{Requests for reprints:}

Mary Pegington, Research Dietitian, Prevent Breast Cancer Research Unit, The Nightingale Centre, Wythenshawe Hospital, Manchester University NHS Foundation Trust, Manchester, M23 9LT, UK.

Telephone: 01612914854

Email: mary.pegington@manchester.ac.uk

\section{Conflict of interest statement:}

The authors declare no conflicts of interest.

\section{Funding statement:}

Tam-Prev was funded by the National Institute for Health Research (NIHR) Research for Patient Benefit (RfPB) Programme (PB-PG-0110-21342) with additional funding from Prevent Breast Cancer (UK charity 1109839). This project was supported by the NIHR Manchester Biomedical Research Centre. The views expressed are those of the authors and not necessarily those of the NHS, the NIHR or the Department of Health. 
ABSTRACT

\section{Lifestyle behaviours and health measures of women at increased risk of breast cancer taking chemoprevention}

\section{Objectives}

Women at increased breast cancer risk are eligible for chemoprevention. Healthy lifestyles are potentially important for these women to improve efficacy and minimise side effects of chemoprevention and reduce risk of breast cancer and other lifestyle related conditions. We investigated whether women taking chemoprevention adhere to healthy lifestyle recommendations, how their lifestyle risk factors and health measures compare to women in the general population, and whether these change whilst taking chemoprevention.

\section{Methods}

Lifestyle risk factors and health measures in 136 premenopausal women taking tamoxifen for prevention of breast cancer (Tam-Prev study) were compared to both national recommendations and an age-matched female population from the Health Survey for England 2012.

\section{Results}

The Tam-Prev population had high rates of overweight and obesity (59.2\%) and low adherence to physical activity recommendations (30.6\%) which were comparable to the general population (respectively 55.2\% and 35.1\%). Fewer Tam-Prev participants were current smokers (10.5\% vs. $18.2 \%, p=0.032)$, but more exceeded alcohol recommendations $(45.0 \%$ vs. $18.7 \%$, p $<0.001)$. Tam-Prev participants had suboptimal diets; proportions not meeting fibre, 
saturated fat and non-milk extrinsic sugar recommendations were $87.8 \%, 64.9 \%$ and $21.4 \%$ respectively. Many Tam-Prev participants had markers of cardiovascular disease risk and the metabolic syndrome. Health behaviours did not change during the first year on tamoxifen.

\section{Conclusions}

Women taking chemoprevention had a high prevalence of unhealthy lifestyle behaviours and health measures, similar to an age-matched English cohort. Improving these measures in women at increased breast cancer risk could significantly decrease rates of breast cancer and other non-communicable diseases.

\section{Keywords:}

Chemoprevention, lifestyle, diet, physical activity, weight, tamoxifen, breast cancer 
TEXT

\section{Lifestyle behaviours and health measures of women at increased risk of breast cancer taking chemoprevention}

\section{Introduction}

Breast cancer (BC) is the most common cancer in the UK with 55,122 diagnoses in 2015 (Cancer Research UK, online). Expert reports estimate maintaining a healthy weight, limiting alcohol, and being physically active could prevent $19-38 \%$ of BC in the UK (World Cancer Research Fund International / American Institute for Cancer Research, online; Parkin, 2011). Further reductions would be achieved through not smoking (Macacu et al., 2015; Kispert and McHowat, 2017).

Tamoxifen is one of three drugs licenced for chemoprevention of $B C$ in women at increased risk of $B C$ in the UK. Tamoxifen reduces $B C$ risk by $40 \%$ but carries an increased risk of venous thromboembolism and postmenopausal endometrial cancer, as well as vasomotor side effects.

Although evidence is mixed, there are suggestions from the adjuvant (Goodwin, 2015) and prevention (Cecchini et al., 2012) settings that chemopreventative medications are less effective in overweight women, and carry more side effects (Cohen et al., 2001; Al-Azemi, Labib and Omu, 2002; Dignam et al., 2003). Furthermore since the majority of women taking chemoprevention will not develop BC (Antoniou et al., 2003), they need to attend to their risk of other lifestyle-related diseases, for example cardiovascular disease (CVD).

There are few published data on the lifestyle behaviours of women at increased risk of BC, and none concerning those behaviours in women taking $B C$ chemoprevention. This paper describes 
the lifestyle behaviours and health measures of women at increased risk of $B C$ opting to take tamoxifen compared to the general UK population, and changes during a year of chemoprevention.

\section{Methods}

\section{Participants}

The Tamoxifen Prevention Study (Tam-Prev, ISRCTN 53844391) was approved by Greater Manchester West Research Ethics Committee (11/H1014/4) and performed in accordance with the Declaration of Helsinki (Donnelly et al., 2014). It recruited 136 premenopausal women at increased risk of $B C$ in 2011-12 to establish uptake of tamoxifen for BC prevention, and to determine who is most likely to benefit.

The Tam-Prev study has been described previously (Donnelly et al., 2014). Women were eligible if they were at moderately high or high risk of $B C$ ( $\geq 17 \%$ lifetime risk) (Tyrer, Duffy and Cuzick, 2004), attending a regional Family History Clinic (FHC), aged 33-46 years, premenopausal and not on hormonal contraception. From 1279 eligible women invited, 136 were recruited (10.6\% uptake), none of whom were known BRCA gene mutation carriers. All participants provided written informed consent.

\section{Procedures}

Women were asked to take tamoxifen $(20 \mathrm{mg} / \mathrm{d})$ and were reviewed at eight weeks and one year. No individualised lifestyle advice was given. All participants had previously been given a leaflet on the lifestyle prevention of $\mathrm{BC}$ upon joining the $\mathrm{FHC}$ which included advice to control weight, limit alcohol and increase physical activity (PA). The median duration from joining the FHC to starting the Tam-Prev study was four years (range 0-19). 
Assessments at baseline (before commencing tamoxifen) and one year included weight and body fat determined by multi-frequency bioelectrical impedance (MC-180MA; Tanita Europe, Amsterdam, The Netherlands), fasting lipids, insulin and glucose taken using standardised methods described previously (Harvie et al., 2013). Self-reported dietary intake was assessed at baseline and one year from seven day food diaries checked for completeness with the respondent and analysed using WISP v3.3 (Tinuviel Software, Anglesey, UK) for mean daily saturated fatty acids, fibre (Association of Official Analytical Chemists [AOAC] method), nonmilk extrinsic sugars (NMES: total of sugars added during manufacturing or before consumption, sugars in honey, syrups and unsweetened fruit juices, and $50 \%$ of sugars from dried, stewed or canned fruit) and alcohol. Self-reported PA in the past seven days was assessed using the International Physical Activity Questionnaire (IPAQ) short version at the same time points (Craig et al., 2003) and was used to calculate Metabolic Equivalent of Task (MET). Walking at 3.0 miles per hour is a 3.3 MET activity, and an hour of brisk walking equates to $3.3 \times 60=198$ MET-minutes.

Insulin was measured by chemiluminescent microparticle immunoassay (ARCHITECT i2000, Abbott, Illinois, USA). Glucose was measured by hexokinase/glucose-6-phosphate inter-assay dehydrogenase method and colorimetric enzyme reactions were used to measure total cholesterol, triglycerides and HDL cholesterol (all ARCHITECT c1600, Abbott, Illinois, USA). Levels were measured spectrophotometrically by an automated Olympus AU600 analyser (Olympus, Rungis, France). LDL cholesterol was calculated using the formula of Friedewald et al (Friedewald, Levy and Fredrickson, 1972). Fasting insulin and glucose were combined to calculate the insulin resistance index using the homeostasis model assessment (HOMA) (Matthews et al., 1985). 


\section{Statistics}

We compared the Tam-Prev population (age, deprivation level, BMI, total and HDL cholesterol, smoking, alcohol and PA habits) to a population of 1072 women aged 33-46 years in the Health Survey for England (HSE) (Craig and Mindell, 2013). The 2012 HSE was used to ensure a comparable time frame. Indices of Deprivation 2007 Layer Super Output Area Scores were identified from participant postcodes via Geoconvert (UK Data Service Census Support, online). There were some methodological differences between the two data sets; PA data were collected in Tam-Prev by the IPAQ short version covering the previous seven days, and in HSE by a longer set of questions covering the previous four weeks (Craig and Mindell, 2013), TamPrev used a seven day food diary to collect dietary data whereas HSE used a verbal food frequency questionnaire. We assessed changes in weight, BMI, body composition and dietary intakes at one year in the Tam-Prev cohort. Changes in lipids, glucose or HOMA were not assessed as these can be altered by tamoxifen (Johansson et al., 2008; Filippatos et al., 2009).

Data were analysed using SPSS v23 (IBM, Armonk, New York, USA). Normally distributed data are presented as mean and SD (age, body fat percentage, total, LDL and HDL cholesterol, glucose, fibre and saturated fat), otherwise median and range are presented. Categorical data are presented as number and percentage (deprivation, smoking, proportion not meeting recommendations for $\mathrm{BMI}$, body fat percentage, lipids, glucose, PA and dietary variables). Independent samples t-tests, Mann-Whitney $U$ tests and Pearson's chi squared tests were used to compare the Tam-Prev and HSE populations at baseline. Changes over one year were calculated for weight, BMI, body fat, PA and the dietary variables using both per protocol and baseline observation carried forward (BOCF) values. Normally distributed change variables 
(weight, BMI, body fat, PA and saturated fat) were compared using paired samples t-tests, otherwise related samples Wilcoxon signed-rank tests were used.

\section{Results}

\section{Baseline characteristics}

The baseline characteristics of Tam-Prev participants are reported in Table 1. The median BMIs of the populations were comparable (median [range] Tam-Prev $25.9[18.4-50.8] \mathrm{kg} / \mathrm{m}^{2}$ and HSE $25.8[15.71-58.44] \mathrm{kg} / \mathrm{m}^{2}, \mathrm{p}=803$ ). Women in Tam-Prev were slightly taller (mean [SD] 1.65 [0.06] vs $1.63[0.06] \mathrm{m}, \mathrm{p}<0.001)$, but were also non-significantly heavier than the HSE population (median [range] 70 [45.5-130.2] vs $68.5[37.5-140.4] \mathrm{kg}, \mathrm{p}=0.106$ ). The majority of women in both populations were either overweight or obese (59.2 and 55.3\% in Tam-Prev and HSE). This aligns with the observation that half of women in Tam-Prev had a body fat percentage above the normal range (Gallagher et al., 2000). The Tam-Prev population was marginally older than the HSE population but had an equivalent spread of deprivation. Mean total cholesterol level was lower in the Tam-Prev population compared to the general population (4.9 [0.8] vs 5.2 [1.0] $\mathrm{mmol} / \mathrm{L}, \mathrm{p}<0.001)$, however the HDL fraction was also lower (1.5 [0.3] vs $1.6[0.4] \mathrm{mmol} / \mathrm{L}, \mathrm{p}<0.001$ ) and $26.7 \%$ of Tam-Prev women had a low HDL level $(<1.29 \mathrm{mmol} / \mathrm{L})$ compared to $17.6 \%$ of the HSE population $(p=0.019)$, which is one of the markers of the metabolic syndrome (International Diabetes Federation, 2006). Other markers of the metabolic syndrome were present in Tam-Prev women; $13.9 \%$ had triglycerides $\geq 1.7$ $\mathrm{mmol} / \mathrm{L}$ and $4.4 \%$ had fasting plasma glucose $\geq 5.6 \mathrm{mmol} / \mathrm{L}$ (International Diabetes Federation, 2006). HOMA, a measure of insulin resistance which increases risk of metabolic syndrome, was increased (>2.5) in 14.1\% of Tam-Prev women (Kuk and Ardern, 2009). 
Table 2 compares health behaviours in the two populations. Smoking was less prevalent amongst the Tam-Prev women (10.5 vs $18.2 \%, p=0.032$ ). A third of women in both populations did not meet PA guidelines. Self-reported median daily alcohol intake was markedly higher in Tam-Prev women (13.6 [0-107.8] vs $3.6[0-680.0]$ g per day, $\mathrm{p}<0.001)$ and $45 \%$ of Tam-Prev participants exceeded the recommended UK maximum of 14 units per week (equivalent to 1.4 bottles of wine or six pints of lager) compared to $18.7 \%$ of the HSE population $(p<0.001)$. Proportions of Tam-Prev women not meeting UK guidelines for fibre, saturated fat and NMES were $88 \%, 65 \%$ and $21 \%$ respectively, though there were no comparable figures for the HSE population.

Of 115 women in Tam-Prev with full information, over half (51\%) had at least two out of four key lifestyle risk factors as defined by the World Cancer Research Fund and the American Institute for Cancer Research (WCRF/AICR: overweight or obesity, low PA, smoking, exceeding seven alcoholic drinks per week: 9-13 units / week), 18\% had at least three, and one participant had all four. Only $8.7 \%$ had a low-risk lifestyle with none of these risk factors (World Cancer Research Fund International / American Institute for Cancer Research, 2007).

\section{Withdrawal from the Tam-Prev Study}

Twenty-seven women (19.9\%) withdrew before one year: 21 (15.4\%) due to tamoxifen side effects, three $(2.2 \%)$ lost contact, one $(0.7 \%)$ became pregnant and two $(1.5 \%)$ left for other reasons. There were no differences in baseline BMI or smoking status between completers and those that dropped out (median BMI [range] 26.3 [18.4-45.7] vs 25.2 [19.5-50.8] kg/m², $p=0.943 ; 10.1$ vs $13.3 \%$ smokers, $p=0.701$ ), however completers had a higher alcohol intake (15.6 [0.0-107.8] vs $4.0[0.0-58.6] \mathrm{g} /$ day, $\mathrm{p}=0.001)$. Three participants took tamoxifen for less than one year but their results are included here as they completed the one year assessments. 


\section{Change after one year of chemoprevention}

Per-protocol analyses are reported in Table 3. BOCF analyses gave similar results (data not shown). There were modest reductions in weight, BMI and body fat mass over the year. Using $\pm 3 \%$ to define natural daily weight variation (Stevens et al., 2006), $23 \%$ of women lost weight, $68 \%$ maintained, and $9 \%$ gained. The proportions losing and gaining a clinically significant $5 \%$ of baseline weight were $15.7 \%$ and $4.6 \%$ respectively (Jensen et al., 2014). There were small reductions in saturated fat $(26.1 \mathrm{~g}$ to $24.0 \mathrm{~g}$ per day, $\mathrm{p}=0.011)$ and NMES $(37.2 \mathrm{~g}$ to $33.7 \mathrm{~g}$ per day, $\mathrm{p}=0.030$ ) during the year, but no change in other dietary parameters or PA. Despite these reductions, significant proportions of the women remained overweight and were not adhering to recommendations for PA, alcohol or diet at one year.

\section{Discussion}

Here we report lifestyle behaviours and health measures in women in an FHC taking tamoxifen for prevention of $\mathrm{BC}$, and the change in these during a year of chemoprevention. At baseline, Tam-Prev participants had a high prevalence of unhealthy lifestyle behaviours, for example overweight, low PA and adverse health measures, which were comparable to an English, agematched female population from the HSE. They reported higher alcohol intake but lower smoking rates. Significant proportions were found to have markers of poor metabolic health and indicators of poor diet.

Previous studies of lifestyle behaviours in women at increased risk of BC in the UK have also highlighted the prevalence of overweight and obesity and low adherence to PA recommendations (Begum et al., 2009; Anderson et al., 2017). Begum et al reported the majority of women (76\%) in an English FHC were overweight or obese and $24 \%$ did no PA 
(Begum et al., 2009), while Anderson et al found $52 \%$ of respondents in a Scottish genetics service were overweight or obese and 55\% did not adhere to PA recommendations (Anderson et al., 2017). Both studies, in addition to Tam-Prev and HSE, used self-reported methods for PA which are acknowledged to overestimate (Boon et al., 2010) so it is likely that actual PA levels were even lower than reported.

The lower rate of smoking in Tam-Prev (10.5\%) compared to the general population (18.2\%) is an interesting observation which has also been noted in women with a family history of breast and/or ovarian cancer undergoing genetic testing (Rouleau et al., 2004). Two UK surveys found many women with a family history of BC incorrectly believe that smoking is the most important risk factors (Begum et al., 2009; Anderson et al., 2017). The low rate of smoking seen here and in the surveys could be due to these beliefs.

Forty-five percent of the Tam-Prev population exceeded alcohol recommendations. The two UK surveys above have found similar (56\%) and much lower (1\%) proportions exceeding recommendations, despite all studies using self-reported data (Begum et al., 2009; Anderson et al., 2017). The apparent greater alcohol intake in the Tam-Prev population compared to HSE data could be the result of a difference in methods; though both were self-reported, HSE used a verbal food frequency questionnaire and Tam-Prev used a seven day food diary which may provide a more honest and accurate reflection of behaviours.

Unhealthy behaviours amongst women with a family history of $B C$ are not confined to the UK. A study of Californian women with a family history of BC found poor adherence to WCRF/AICR healthy living recommendations (World Cancer Research Fund International / American Institute for Cancer Research, 2007; Bostean, Crespi and McCarthy, 2013) as did a study of 
female BRCA mutation carriers in The Netherlands using data collected between 1996 and 2012 (World Cancer Research Fund International / American Institute for Cancer Research, 2007; van Erkelens et al., 2017).

Studies have found minimal or no change in lifestyle after BRCA counselling (O'Neill et al., 2008; Quach et al., 2009; Spector et al., 2009). This is supported by a recent meta-analysis which found that disease risk information, even when personalised, does not have a strong effect on behaviour (French et al., 2017). Belief in the efficacy of certain health behaviours to prevent or delay cancer has been associated with practice of these behaviours (Quach et al., 2009). Therefore efforts to encourage behaviour change in FHCs should include education to address current poor understanding and improve credibility of lifestyle risk factors, and their response efficacy. The National Institute for Health and Care Excellence (NICE) recommend that women with a family history of $B C$ in the UK receive written information on lifestyle, including diet, PA and alcohol (NICE, 2013). Despite previously receiving written information the Tam-Prev population had a high prevalence of unhealthy lifestyle behaviours. This is consistent with previous data highlighting the limited efficacy of standard written advice (Mazzuca, 1982). An effective lifestyle intervention would include education around lifestyle risk factors, combined with an programme proven to aid behaviour change such as a selfmonitoring website with additional telephone calls (Cadmus-Bertram et al., 2013; Hartman et al., 2015).

Tam-Prev participants completed food diaries at baseline and one year in the study which are known to promote behaviour change (Burke, Wang and Sevick, 2011) and could have contributed to the small improvements in weight and diet seen here. Sixteen percent of women achieved a clinically significant $5 \%$ weight loss. Our results agree with previous 
research showing that tamoxifen does not cause weight gain in the prevention setting (Sestak et al., 2012).

Women about to commence tamoxifen had lower levels of total and HDL cholesterol than women in the general population. Two studies by Boyd et al reported generally more favourable lipid profiles in women with a family history of $B C$, but findings were variable and the reasons for these potential differences are not understood (Boyd et al., 1989, 1995). Women with a family history of $\mathrm{BC}$ are reported to underestimate their CVD risk and overestimate their BC risk (Erblich et al., 2000) and our results suggest that a significant proportion of Tam-Prev women had an increased risk of CVD at baseline of which they may have been unaware. Despite tamoxifen provoking beneficial reductions in total and LDLcholesterol levels, it does not consistently lead to lower CVD rates, perhaps due to detrimental effects on triglyceride levels (Filippatos et al., 2009) insulin sensitivity (Johansson et al., 2008), and thromboembolism, thus other methods of reducing CVD risk in these women, such as lifestyle change, should be encouraged.

This is the first prospective study on lifestyle behaviours and health measures in women undertaking $B C$ chemoprevention. It benefits from an almost complete data set for women who entered Tam-Prev. Most of the Tam-Prev and HSE data were gathered using similar methods though a weakness is that PA and alcohol methods were different. Another weakness is that we do not have data on change over a year in higher risk women not taking tamoxifen, therefore cannot assess whether the changes observed here would normally be expected over time. Dietary and PA data were self-reported and people tend to underestimate amounts eaten and overestimate PA (Mertz et al., 1991; Lichtman et al., 1992; Boon et al., 2010). It is recognised that this could affect both data sets. 
This population of higher risk women taking chemoprevention had a high prevalence of suboptimal lifestyle behaviours. We have not compared the Tam-Prev population to higher risk women in general who are not taking tamoxifen. Women who opt to take chemoprevention could have different behaviours to other high risk women. However our data is consistent with rates of suboptimal behaviours from previous surveys in the general high risk population. This study highlights the need to initiate lifestyle change programmes in FHCs. Future research should focus on engaging higher risk women with lifestyle improvement. This should reduce the burden of $B C$ and other lifestyle-related diseases, leading to potential improvements in quality of life, and cost savings for the NHS.

\section{Acknowledgements}

Food diary analysis by Ellen Mitchell, Debbie McMullan and Rebecca Dodd-Chandler. Assistance with data analysis from Phil Foden. Study execution and data collection by Paula Stavrinos, Rosemary Greenhalgh, Jill Fox, Katharine Sellers and Jayne Beesley. Proof reading by Cheryl Lombardelli. 


\section{References}

Al-Azemi M, Labib NS and Omu AE (2002) ‘Endometrial changes in post-menopausal breast cancer patients on tamoxifen', Int. J. Gynecol. Obstet., 79(1), pp. 47-49.

Anderson AS, Caswell S, Macleod M, Steele RJ, Berg J, Dunlop J, et al. (2017) 'Health Behaviors and their Relationship with Disease Control in People Attending Genetic Clinics with a Family History of Breast or Colorectal Cancer', J. Genet. Couns., 26(1), pp. 40-51.

Antoniou A, Pharoah PDP, Narod S, Risch HA, Eyfjord JE, Hopper JL, et al. (2003) 'Average Risks of Breast and Ovarian Cancer Associated with BRCA1 or BRCA2 Mutations Detected in Case Series Unselected for Family History: A Combined Analysis of 22 Studies', Am. J. Hum. Genet., 72(5), pp. 1117-1130.

Begum P, Richardson CE, Carmichael AR, Lahmann P, Hoffmann K, Allen N, et al. (2009)

'Obesity in post menopausal women with a family history of breast cancer: prevalence and risk awareness', Int. Semin. Surg. Oncol., 6(1), p. 1.

Boon RM, Hamlin MJ, Steel GD and Ross JJ (2010) 'Validation of the New Zealand physical activity questionnaire (NZPAQ-LF) and the international physical activity questionnaire (IPAQLF) with accelerometry', Br. J. Sports Med., 44(10), pp. 741-746.

Bostean G, Crespi CM and McCarthy WJ (2013) 'Associations among family history of cancer, cancer screening and lifestyle behaviors: a population-based study', Cancer Causes Control, 24(8), pp. 1491-1503.

Boyd NF, Connelly P, Lynch H, Knaus M, Michal S, Fili M, et al. (1995) ‘Plasma Lipids, Lipoproteins, and Familial Breast Cancer', Cancer Epidemiol. Biomarkers Prev., 4(2), pp. 117122.

Boyd NF, McGuire V, Fishell E, Kuriov V, Lockwood G and Tritchler D (1989) ‘Plasma lipids in premenopausal women with mammographic dysplasia.', Br. J. Cancer, 59, pp. 766-771.

Burke LE, Wang J and Sevick MA (2011) 'Self-Monitoring in Weight Loss: A Systematic Review 
of the Literature', J. Am. Diet. Assoc., 111(1), pp. 92-102.

Cadmus-Bertram L, Wang JB, Patterson RE, Newman VA, Parker BA and Pierce JP (2013) 'Webbased self-monitoring for weight loss among overweight/obese women at increased risk for breast cancer: The HELP pilot study', Psychooncology., 22(8), pp. 1821-1828.

Cancer Research UK (online) Breast cancer incidence (invasive) statistics. Available at: http://www.cancerresearchuk.org/health-professional/cancer-statistics/statistics-by-cancertype/breast-cancer/incidence-invasive (Accessed: 12 March 2018).

Cecchini RS, Costantino JP, Cauley JA, Cronin WM, Wickerham DL, Land SR, et al. (2012) ‘Body mass index and the risk for developing invasive breast cancer among high-risk women in NSABP P-1 and STAR breast cancer prevention trials.', Cancer Prev. Res. (Phila)., 5(4), pp. 58392.

Cohen I, Azaria R, Bernheim J, Shapira J and Beyth Y (2001) 'Risk factors of endometrial polyps resected from postmenopausal patients with breast carcinoma treated with tamoxifen', Cancer, 92(5), pp. 1151-1155.

Craig CL, Marshall AL, Sjöström M, Bauman AE, Booth ML, Ainsworth BE, et al. (2003) 'International physical activity questionnaire: 12-Country reliability and validity', Med. Sci. Sports Exerc., 35(8), pp. 1381-1395.

Craig R and Mindell J (eds) (2013) Health Survey for England 2012: Health, social care and lifestyles. Volume 1: Health, social care and lifestyles. Volume 2: Methods and documentation. Department of Health (1991) Dietary reference values for food energy and nutrients for the United Kingdom. Report of the Panel on Dietary Reference Values of the Committee on Medical Aspects of Food Policy., Rep. Health Soc. Subj. (Lond).

Dignam JJ, Wieand K, Johnson KA, Fisher B, Xu L and Mamounas EP (2003) ‘Obesity, tamoxifen use, and outcomes in women with estrogen receptor-positive early-stage breast cancer.', J. Natl. Cancer Inst., 95(19), pp. 1467-76. 
Donnelly LS, Evans DG, Wiseman J, Fox J, Greenhalgh R, Affen J, et al. (2014) ‘Uptake of tamoxifen in consecutive premenopausal women under surveillance in a high-risk breast cancer clinic', Br. J. Cancer, 110(7), pp. 1681-1687.

Erblich J, Bovbjerg DH, Norman C, Valdimarsdottir HB and Montgomery GH (2000) 'It won't happen to me: Lower perception of heart disease risk among women with family histories of breast cancer', Prev. Med. (Baltim)., 31(6), pp. 714-721.

van Erkelens A, Derks L, Sie AS, Egbers L, Woldringh G, Prins JB, et al. (2017) ‘Lifestyle Risk Factors for Breast Cancer in BRCA1/2-Mutation Carriers Around Childbearing Age', J. Genet. Couns., 26(4), pp. 785-791.

Filippatos TD, Liberopoulos EN, Pavlidis N, Elisaf MS and Mikhailidis DP (2009) 'Effects of hormonal treatment on lipids in patients with cancer', Cancer Treat. Rev., 35(2), pp. 175-184. French DP, Cameron E, Benton JS, Deaton C and Harvie M (2017) 'Can Communicating Personalised Disease Risk Promote Healthy Behaviour Change? A Systematic Review of Systematic Reviews', Ann. Behav. Med., 51(5), pp. 718-729.

Friedewald WT, Levy RI and Fredrickson DS (1972) 'Estimation of the concentration of lowdensity lipoprotein cholesterol in plasma, without use of the preparative ultracentrifuge.', Clin. Chem., 18(6), pp. 499-502.

Gallagher D, Heymsfield SB, Heo M, Jebb SA, Murgatroyd PR and Sakamoto Y (2000) ‘Healthy percentage body fat ranges: an approach for developing guidelines based on body mass index.', Am. J. Clin. Nutr., 72(3), pp. 694-701.

Goodwin PJ (2015) 'Obesity, insulin resistance and breast cancer outcomes.', Breast, 24, pp. S56-S59.

Hartman SJ, Dunsiger SI, Marinac CR, Marcus BH, Rosen RK and Gans KM (2015) 'Internetbased physical activity intervention for women with a family history of breast cancer', Heal. Psychol., 34(0), pp. 1296-1304. 
Harvie M, Wright C, Pegington M, McMullan D, Mitchell E, Martin B, et al. (2013) 'The effect of intermittent energy and carbohydrate restriction v. daily energy restriction on weight loss and metabolic disease risk markers in overweight women', Br. J. Nutr., 110(8), pp. 1534-1547. International Diabetes Federation (2006) IDF Consensus Worldwide Definition of the Metabolic Syndrome.

Jensen MD, Ryan DH, Donato KA, Apovian CM, Ard JD, Comuzzie AG, et al. (2014) 'Executive summary: Guidelines (2013) for the management of overweight and obesity in adults', Obesity, 22(S2), pp. S5-S39.

Johansson H, Gandini S, Guerrieri-Gonzaga A, lodice S, Ruscica M, Bonanni B, et al. (2008) 'Effect of Fenretinide and Low-Dose Tamoxifen on Insulin Sensitivity in Premenopausal Women at High Risk for Breast Cancer', Cancer Res, 68(22), pp. 9512-8.

Kispert S and McHowat J (2017) 'Recent insights into cigarette smoking as a lifestyle risk factor for breast cancer.', Breast cancer, 9, pp. 127-132.

Kuk JL and Ardern Cl (2009) 'Are metabolically normal but obese individuals at lower risk for all-cause mortality?', Diabetes Care, 32(12), pp. 2297-9.

Lichtman SW, Pisarska K, Berman ER, Pestone M, Dowling H, Offenbacher E, et al. (1992) 'Discrepancy between Self-Reported and Actual Caloric Intake and Exercise in Obese Subjects', N. Engl. J. Med., 327(27), pp. 1893-1898.

Macacu A, Autier P, Boniol M and Boyle P (2015) 'Active and passive smoking and risk of breast cancer: a meta-analysis', Breast Cancer Res. Treat., 154(2), pp. 213-224.

Matthews DR, Hosker JP, Rudenski AS, Naylor BA, Treacher DF and Turner RC (1985) 'Homeostasis model assessment: insulin resistance and beta-cell function from fasting plasma glucose and insulin concentrations in man.', Diabetologia, 28(7), pp. 412-9. Mazzuca SA (1982) 'Does patient education in chronic disease have therapeutic value?', J. Chronic Dis., 35(7), pp. 521-529. 
Mertz W, Tsui JC, Judd JT, Reiser S, Hallfrisch J, Morris ER, et al. (1991) 'What are people really eating? The relation between energy intake derived from estimated diet records and intake determined to maintain body weight.', Am. J. Clin. Nutr., 54(2), pp. 291-5.

NICE (2013) Clinical guideline CG164. Familial breast cancer: classification, care and managing breast cancer and related risks in people with a family history of breast cancer.

NICE (2014) Clinical guideline CG189. Obesity: identification, assessment and management. O’Neill SC, Kaufman E, DeMarco T, Peshkin BN, McKenna K, Shelby R, et al. (2008) 'Changes in diet and physical activity following BRCA1/2 testing.', J. Psychosoc. Oncol., 26(3), pp. 63-80. Parkin DM (2011) 'Cancers attributable to consumption of alcohol in the UK in 2010', Br. J. Cancer, 105, pp. S14-S18.

Quach J, Porter K, Leventhal H and Kelly KM (2009) 'Health behaviors among Ashkenazi Jewish individuals receiving counseling for BRCA1 and BRCA2 mutations', Fam. Cancer, 8(3), pp. 241250.

Rouleau I, Chiquette J, Plante M, Simard J and Dorval M (2004) 'Changes in Health-Related Behaviours Following BRCA 1/2 Genetic Testing: The Case of Hormone Replacement Therapy', J. Obstet. Gynaecol. Canada, 26, pp. 1059-1066.

Sestak I, Harvie M, Howell A, Forbes JF, Dowsett M and Cuzick J (2012) 'Weight change associated with anastrozole and tamoxifen treatment in postmenopausal women with or at high risk of developing breast cancer', Breast Cancer Res. Treat., 134(2), pp. 727-734. Spector D, Mishel M, Skinner CS, Deroo LA, Vanriper M and Sandler DP (2009) 'Breast cancer risk perception and lifestyle behaviors among White and Black women with a family history of the disease.', Cancer Nurs., 32(4), pp. 299-308.

Stevens J, Truesdale K, Mcclain J and Cai J (2006) 'The definition of weight maintenance', Int. J. Obes., 30, pp. 391-399.

Tyrer J, Duffy SW and Cuzick J (2004) ‘A breast cancer prediction model incorporating familial 
and personal risk factors', Stat. Med., 23(7), pp. 1111-1130.

UK Data Service Census Support (online) Office for National Statistics, Postcode Directories.

Available at: http://edina.ac.uk/census / http://geoconvert.ukdataservice.ac.uk (Accessed: 30 November 2016).

WHO (1995) 'Physical status: the use and interpretation of anthropometry. Report of a WHO Expert Committee.', World Health Organ. Tech. Rep. Ser., pp. 1-452.

World Cancer Research Fund International / American Institute for Cancer Research (2007) Food, Nutrition, Physical Activity, and the Prevention of Cancer: a Global Perspective. World Cancer Research Fund International / American Institute for Cancer Research (online) Cancer preventability estimates. Available at: Available at wcrf.org/cancer-preventabilityestimates (Accessed: 2 March 2017). 
Table 1: Baseline characteristics of women in the Tam-Prev study compared to an age matched women in the general population in England

Tam-Prev English population ${ }^{1} \quad$ P value

population

\begin{tabular}{|c|c|c|c|}
\hline Age (years) ${ }^{2}$ & $\begin{array}{l}41.2(3.5) \\
(n=136)\end{array}$ & $\begin{array}{l}39.7(4.0) \\
(n=1072)\end{array}$ & $<0.001$ \\
\hline \multicolumn{4}{|l|}{ Indices of Deprivation ${ }^{3}$} \\
\hline 1 (least deprived) & $33(24.3 \%)$ & $234(21.8 \%)$ & 0.439 \\
\hline 2 & $34(25.0 \%)$ & $209(19.5 \%)$ & \\
\hline 3 & $24(17.6 \%)$ & $217(20.2 \%)$ & \\
\hline 4 & $25(18.4 \%)$ & $210(19.6 \%)$ & \\
\hline \multirow[t]{2}{*}{5 (most deprived) } & $20(14.7 \%)$ & $202(18.8 \%)$ & \\
\hline & $(n=136)$ & $(n=1072)$ & \\
\hline \multirow[t]{2}{*}{ Height $(\mathrm{m})^{2}$} & $1.65(0.06)$ & $1.63(0.06)$ & $<0.001$ \\
\hline & $(n=130)$ & $(n=955)$ & \\
\hline \multirow[t]{2}{*}{ Weight (kg) ${ }^{4}$} & $70(45.5-130.2)$ & $68.5(37.5-140.4)$ & 0.106 \\
\hline & $(n=130)$ & $(n=898)$ & \\
\hline \multirow[t]{2}{*}{ BMI $\left(\mathrm{kg} / \mathrm{m}^{2}\right)^{4}$} & $25.9(18.4-50.8)$ & $25.8(15.71-58.44)$ & 0.803 \\
\hline & $(n=130)$ & $(n=894)$ & \\
\hline BMI category ${ }^{3,5}$ & & & 0.709 \\
\hline Underweight $\left(<18.5 \mathrm{~kg} / \mathrm{m}^{2}\right)$ & $1(0.8 \%)$ & $14(1.6 \%)$ & \\
\hline Normal $\left(18.5-24.9 \mathrm{~kg} / \mathrm{m}^{2}\right)$ & $52(40.0 \%)$ & $386(43.2 \%)$ & \\
\hline Overweight $\left(25-29.9 \mathrm{~kg} / \mathrm{m}^{2}\right)$ & $46(35.4 \%)$ & $279(31.2 \%)$ & \\
\hline
\end{tabular}




\begin{tabular}{|c|c|c|c|}
\hline Obese $\left(\geq 30.0 \mathrm{~kg} / \mathrm{m}^{2}\right)$ & $\begin{array}{c}31(23.8 \%) \\
(n=130)\end{array}$ & $\begin{array}{c}215(24.0 \%) \\
(n=894)\end{array}$ & \\
\hline Body fat percentage (\%) ${ }^{6}$ & $\begin{array}{l}34.2(7.3) \\
(n=130)\end{array}$ & No data & - \\
\hline $\begin{array}{l}\text { Body fat percentage over the ideal } \\
\text { for their age }{ }^{7}\end{array}$ & $50 \%$ & No data & - \\
\hline Total cholesterol $(\mathrm{mmol} / \mathrm{L})^{2}$ & $\begin{array}{l}4.9(0.8) \\
(n=135)\end{array}$ & $\begin{array}{l}5.2(1.0) \\
(n=488)\end{array}$ & $<0.001$ \\
\hline $\mathrm{LDL}$ cholesterol $(\mathrm{mmol} / \mathrm{L})^{6}$ & $\begin{array}{l}3.0(0.7) \\
(n=135)\end{array}$ & No data & - \\
\hline HDL cholesterol (mmol/L) ${ }^{2}$ & $\begin{array}{l}1.5(0.3) \\
(n=135)\end{array}$ & $\begin{array}{l}1.6(0.4) \\
(n=488)\end{array}$ & $<0.001$ \\
\hline HDL cholesterol $<1.29 \mathrm{mmol} / \mathrm{L}^{3,8}$ & $26.7 \%$ & $17.6 \%$ & 0.019 \\
\hline Triglycerides $(\mathrm{mmol} / \mathrm{L}){ }^{10}$ & $\begin{array}{c}0.8(0.3-3.1) \\
(n=136)\end{array}$ & No data & - \\
\hline Triglyceride level $\geq 1.7 \mathrm{mmol} / \mathrm{L}^{8}$ & $13.9 \%$ & & \\
\hline Glucose $(\mathrm{mmol} / \mathrm{L})^{6}$ & $\begin{array}{l}4.7(0.4) \\
(n=136)\end{array}$ & No data & - \\
\hline Glucose $\geq 5.6 \mathrm{mmol} / \mathrm{L}^{8}$ & $4.4 \%$ & & \\
\hline HOMA insulin resistance ${ }^{9}$ & $\begin{array}{c}1.5(0.4-6.1) \\
(n=135)\end{array}$ & No data & - \\
\hline HOMA insulin resistance $\geq \mathbf{2 . 5}{ }^{10}$ & $14.1 \%$ & & \\
\hline
\end{tabular}


${ }^{1}$ (Craig and Mindell, 2013), ${ }^{2}$ Mean (SD) and independent samples t-test, ${ }^{3}$ Percentage and Pearson's chi squared, ${ }^{4}$ Median (range) and Mann Whitney U test, ${ }^{5}$ (WHO, 1995), ${ }^{6}$ Mean (SD), ${ }^{7}$ (Gallagher et al., 2000), ${ }^{8}$ (International Diabetes Federation, 2006), ${ }^{9}$ Median (range), ${ }^{10}$ (Kuk and Ardern, 2009) 
Table 2: Baseline health behaviours of women in the Tam-Prev study compared to an age matched women in the general population in England

Tam-Prev English population ${ }^{1} \quad$ P value
population

\begin{tabular}{|c|c|c|c|}
\hline Smoker ${ }^{2}$ & $\begin{array}{l}10.5 \% \\
(n=124)\end{array}$ & $\begin{array}{c}18.2 \% \\
(n=1071)\end{array}$ & 0.032 \\
\hline $\begin{array}{l}\text { Do not meet physical activity } \\
\text { guidelines }^{2,3} \\
\text { (minimum } 150 \mathrm{~min} / \text { week moderate } \\
\text { intensity or } 75 \mathrm{~min} / \text { week vigorous } \\
\text { intensity physical activity or a } \\
\text { combination) }\end{array}$ & $\begin{array}{l}30.6 \% \\
(n=134)\end{array}$ & $\begin{array}{c}35.1 \% \\
(n=1059)\end{array}$ & 0.229 \\
\hline Alcohol intake (g per day) ${ }^{4}$ & $13.6(0-107.8)$ & $3.6(0-680.0)$ & $<0.001$ \\
\hline $\begin{array}{l}\text { Exceed UK guidelines of } \leq 14 \text { units per } \\
\text { week }^{2} \\
\text { ( } 8 g=1 \text { unit of alcohol) }\end{array}$ & $\begin{array}{l}45.0 \% \\
(n=131)\end{array}$ & $\begin{array}{c}18.7 \% \\
(n=1049)\end{array}$ & $<0.001$ \\
\hline Fibre (g per day) ${ }^{5}$ & $17.5(5.3)$ & No data & - \\
\hline $\begin{array}{l}\text { Do not meet UK daily } \\
\text { recommendation of }>24 \mathrm{~g} / \text { day }^{6}\end{array}$ & $87.8 \%$ & & \\
\hline Saturated fat (g per day) ${ }^{5}$ & $26.1(10.3)$ & No data & - \\
\hline
\end{tabular}


Percentage of daily energy from $12.4(3.1) \%$

saturated fat ${ }^{5}$

Exceed UK recommendation of $<11 \%$

of energy ${ }^{6}$

Non-milk extrinsic sugar (g per day) ${ }^{7} \quad 37.2(0.1-145.1)$

No data

Percentage of daily energy from non-

$8.1(4.6) \%$

milk extrinsic sugars ${ }^{5}$

Exceed UK recommendation of $<11 \%$

$21.4 \%$

of energy ${ }^{6}$

${ }^{1}$ (Craig and Mindell, 2013), ${ }^{2}$ Percentage and Pearson's chi squared, ${ }^{3}$ Physical activity data for Tam-Prev collected using IPAQ short version covering the previous seven days, HSE used a longer set of questions covering the previous four weeks, ${ }^{4}$ Median (range) and Mann Whitney U test, ${ }^{5}$ Mean (SD), ${ }^{6}$ (Department of Health, 1991), ${ }^{7}$ Median (range) 
Table 3: Per-protocol analysis of change at one year

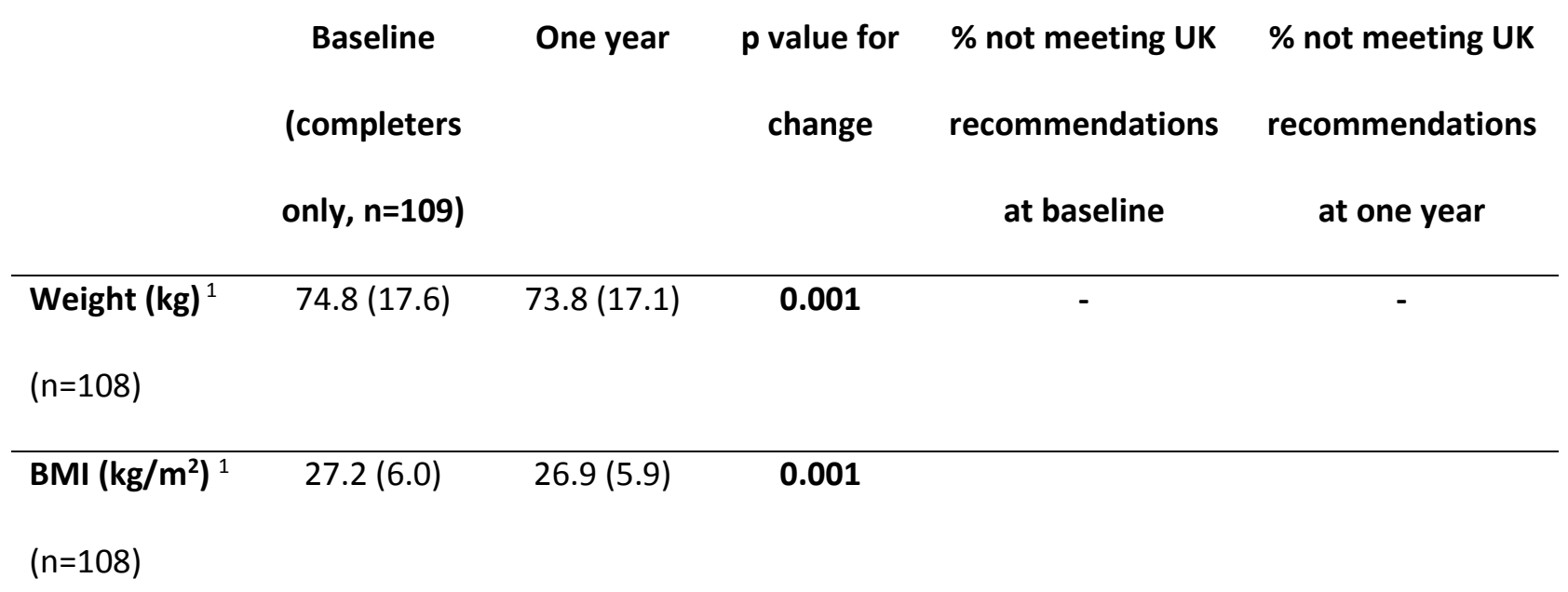

\section{BMI category}

2

Underweight

$0.9 \%$

$0.9 \%$

$\left(<18.5 \mathrm{~kg} / \mathrm{m}^{2}\right)$

Normal (18.5

$39.8 \%$

$43.5 \%$

$\left.-24.9 \mathrm{~kg} / \mathrm{m}^{2}\right)$

Overweight

$35.2 \%$

$31.5 \%$

$(25-29.9$

$\mathrm{kg} / \mathrm{m}^{2}$ )

Obese $(\geq 30.0$

$24.1 \%$

$24.1 \%$

$\mathrm{kg} / \mathrm{m}^{2}$ )

\begin{tabular}{llll}
\hline Body fat $(\mathrm{kg})^{1}$ & $26.6(11.7)$ & $26.0(11.6)$ & $\mathbf{0 . 0 1 0}$
\end{tabular}

$(n=108)$

Physical

3249 (2750)

3054 (2473)

0.719

$30.3 \%$

$27.6 \%$

activity 


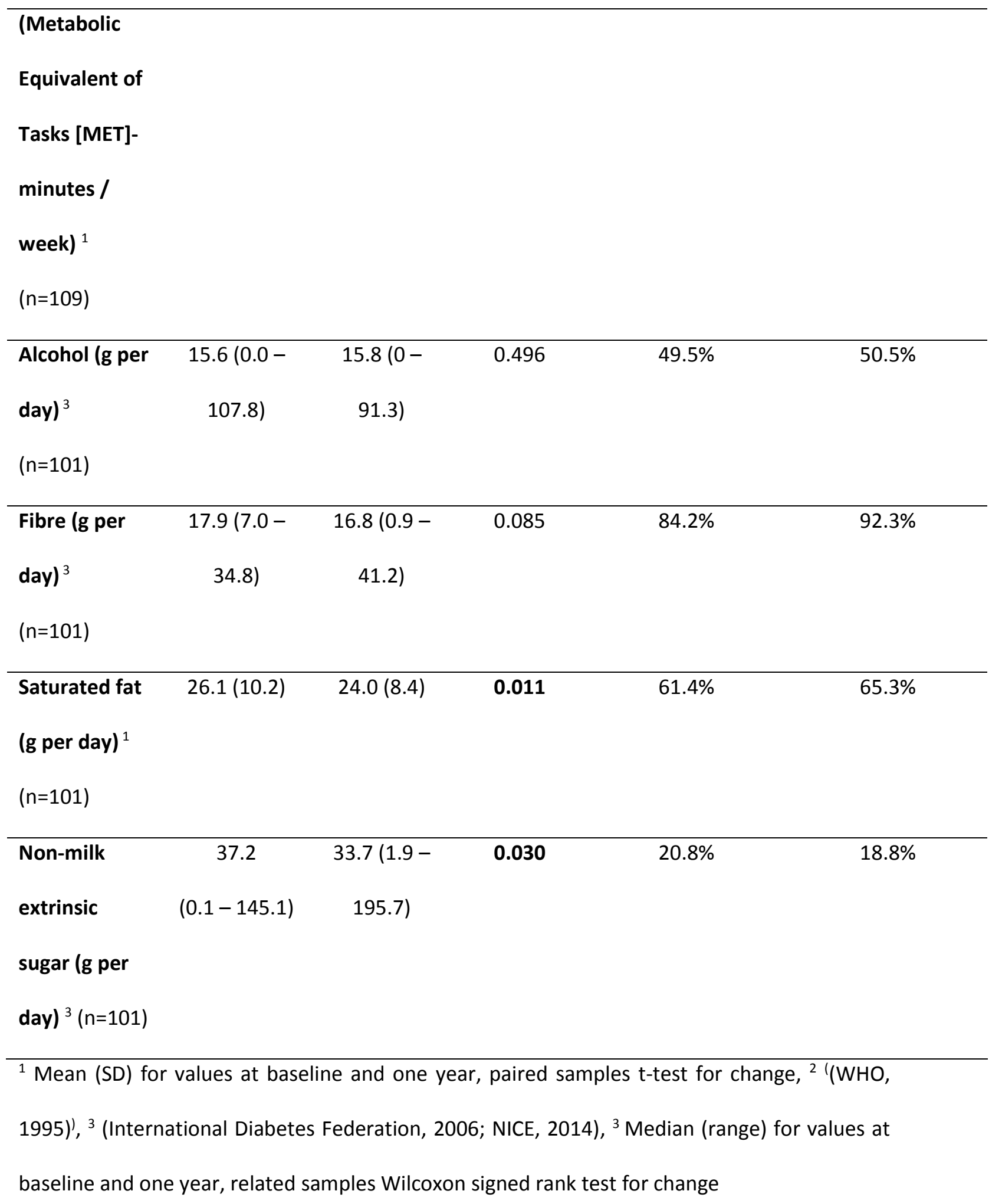

